This is an author produced version of a paper published in Journal Of Rural Studies.

This paper has been peer-reviewed but may not include the final publisher proof-corrections or pagination.

Citation for the published paper:

Erica von Essen, Hans Peter Hansen, Helena Nordström Källström, M. Nils Peterson, Tarla R. Peterson. (2015) The radicalisation of rural resistance:

How hunting counterpublics in the Nordic countries contribute to illegal hunting. Journal Of Rural Studies. Volume: 39, pp 199-209.

http://dx.doi.org/10.1016/j.jrurstud.2014.11.001.

Access to the published version may require journal subscription.

Published with permission from: Elsevier.

Standard set statement from the publisher:

(C) Elsevier, 2015 This manuscript version is made available under the CC-BY-NC-ND 4.0 license http://creativecommons.org/licenses/by-nc-nd/4.0/

Epsilon Open Archive http://epsilon.slu.se 


\title{
The radicalisation of rural resistance: how hunting counterpublics in the Nordic countries contribute to illegal hunting
}

\begin{abstract}
:
Populist hunting movements have risen in recent years to safeguard rural interests against nature conservation.

In extreme cases this movement has been accompanied by the illegal hunting of protected species. Using

Sweden and Finland as a case study, the article elucidates how the perceived exclusion of hunters in the public

debate on conservation mobilised this subculture toward resistance against regulatory agencies. Establishment of an alternative discursive platform comprising several ruralities - counterpublic in Negt and Kluge's original term - allowed hunters to publicise oppositional needs, interests and rationalities in the debate, and was a key juncture in their radicalisation trajectory. Finally the paper argues that failure to grant recognition to the counterpublic radicalised some individuals beyond counterpublic by engaging in illegal hunting. This practice is marked by the termination of political debate with society and represents a danger to political legitimacy.
\end{abstract}

Keywords: radicalisation; poaching; subculture; illegal hunting; rural resistance; recognition

Running head: Radicalisation of rural resistance 


\section{INTRODUCTION}

From a state-centric perspective, the radicalisation of social groups represents a potential threat to political stability. Failure to address this through fundamental restructuring of the premises that promote populist movements, namely their inclusion in the public debate, can result in extremist practices (Nagtzaam and Lentini, 2008). The radicalisation of marginalised social groups in society has recently become apparent in the rise of populist hunting and ruralist movements in Europe in response to EU conservation policy infringing on traditional ways of life in the countryside (Bisi et al., 2007; Ekengren, 2012; Mischi, 2013).

Given the traditionally strong role of the state and high trust in politicians compared to that of other European countries (Holmberg and Weibull, 2011) it is significant that hunters in the Nordic countries have mobilised in opposition to the large carnivore management regime established largely through the EU Habitats Directive (92/43/EEC). Deliberately disruptive conduct including political activism, sit-ins, violent threats and boycotts of game management duties has increasingly been undertaken to challenge the authorities that represent conservation policy. In an extreme development, recalcitrant hunters have taken to breaking the law by killing protected wolves (Liberg et al., 2012) in defence of their livelihoods and lifestyles (Pyka et al., 2007). As a form of everyday resistance, illegal hunting provides a continuity of livelihood practices as well as means of challenging the legitimacy of the regulatory agencies in the struggle for recognition. The struggle for recognition by excluded groups has been seen has primary motivation for social resistance (Honneth, 1995). This struggle, moreover, incites conflict when interacting with polemical material interests.

Moving from distrust of authorities to committing acts of illegal hunting remains the radicalisation of a minority. For this reason going from being a dissenting hunter under the current regime, to becoming mobilised in a contestatory public, to breaking the law to protect 
one's lifestyle should be seen as one alarming potential trajectory of hunters. The objective of this paper is to uncover the radicalisation of resistance that has culminated in illegal hunting. Although still a minority in the Nordic countries, the counterpublic opposed to the regime has gained a foothold among hunters and rural communities in part by positioning wolf reintroduction and EU rewilding directives as the territorialisation of rural space (Ekengren, 2012).

Our use of the term rural encompasses the social-economic, the socio-cultural and the visual-figurative, which in the Nordic countries have been posited to heavily converge at a nexus of the agrarian (Huigen et al., 2000). Beyond territoriality in agrarian landscapes and their surrounding plentiful forests in Finland and Sweden, rurality frequently draws from an imagined storehouse of idyllic-pastoral, but also hardy and pure ways of life and traditional livelihoods. We suggest that in contested nature conservation projects, it is helpful to think of rural as both socially constructed and rhetorically constituted (Woods, 2005; Duenckmann, 2010). Though the latter, sympathy for marginalised ruralities following the appropriation of cultural rural landscapes has generated scepticism toward the state. As evidence of this in Nordic wolf reintroduction, trust in authorities has declined significantly among the general public (Ericsson et al., 2012) and public attitudes have become more forgiving toward illegal hunting in the countryside (Bisi et al., 2007; Krange and Skogen, 2011; Peltola et al., 2013). This predicament suggests the need for a deeper understanding of the societal processes of exclusion that culminate in the illegal hunting phenomenon in rural areas.

These processes, however, are poorly understood. The question at hand, therefore, is what characterises the radicalisation trajectory of law-abiding hunters to illegal hunters on a societal level. A guiding framework for the radicalisation trajectory in this case study is provided by McCauley and Moskalenko (2008). This in turn is based on belief domains that propel groups toward conflict (Eidelson and Eidselson, 2003). McCauley and Moskalenko 
(2008) demarcated four main concepts in the radicalisation of a subculture: the perception that it is special and entitled (superiority), that it has been unfairly treated and betrayed (injustice), that no one cares about it enough to help it (distrust), and that in the present situation the cause and the subculture are in danger of extinction (vulnerability).

Sweden and Finland provide an intuitive context for the case study of the illegal hunting phenomenon given shared socio-demographic premises for hunting (Hansen et al., 2012) common large carnivore conservation commitments under the EU Habitats Directive, strong corporatist traditions in game management (Sandström et al., 2009) and similar intensification of the wolf reintroduction conflict in the past two decades.. To illustrate the radicalisation process of hunters we start with a sketch of the hunting cultures in Sweden and Finland at four major junctures in their trajectory toward endorsement of illegal hunting. This radicalisation, we emphasise, should be seen as an outcome of the dialectic between the hunting subculture and majority society (Arnold, 1970; Fraser, 1990; McCauley and Moskalenko, 2009). On the one hand, stigmatising those who exercise customary rights as radicals illustrates the political and relative construct of radicalisation. Mindful of this, we apprehend radicalisation as a process of de-legitimation through which the individual retreats further into his or her own group, because he or she no longer feels part of society or confident in the system (Schmid, 2013). Parallel to this we discern an increasing commitment to and intensification of existing beliefs.

In this radicalisation sketch, it is first postulated that hunting was a key tenet of majority culture in these countries. Second, the hunting culture is seen from the perspective of its members as being relegated to subculture status with weakened legitimacy in modern society. At the third juncture in its trajectory we trace how the perceived marginalisation of the hunting subculture's knowledge, rationalities and values in decision-making on matters that concern its members have promoted radicalisation of the subculture into a counterpublic 
(Negt and Kluge, 1972). We use counterpublic in Negt and Kluge’s original formulation as an oppositional public comprised of interests and rationalities excluded from the dominant public sphere. By construing counterpublic as the next step of a radicalised subculture, moreover, this paper provides an answer to the uncertainty of counterpublic origin articulated within recent scholarship (Ferguson, 2010). Finally, in a novel contribution, the paper argues that the illegal hunting phenomenon in the Nordic countries has moved beyond the boundaries of a counterpublic; some hunters have terminated communication with the rest of society, turning inwards to a personally relevant collective that make their own rules.

\subsection{The communication of illegal hunting}

The above contention merits some clarification. The majority of illegal hunting in Nordic countries adheres to the covert, private and non-communicative practice of 'shoot, shovel, and shut up' (Liberg et al., 2012). This may be intuitive given open defiance is precluded through tactical wisdom concerning incrimination. Through its tacit nature illegal hunting operates beyond public parameters. Premised on this low profile, illegal hunting has been construed as a form of everyday resistance by the subordinate against the regime in times of oppression (Scott, 1985). Such resistance, Scott (1985) writes, is mediated by and reflects the conditions and constraints under which it is generated. Given the multifunctionality of these practices, which comprise livelihood motives in addition to serving as protest, it is often an epistemological challenge to ascertain the relative resistance content of illegal hunting.

There have, nevertheless, been occurrences in which illegal hunting has risen to the surface of the public sphere as explicit resistance. These have included message crimes against authorities (Pyka et al., 2007; von Essen et al., 2014) epitomised by the serial wolf killer and activist Kari Tikkunen in Finland (Oinaala, 2012). These represent crimes which have a target that is more important than the immediate victim. Such message crimes parallel 
hate crimes, terrorism, and racial and honour killings. Message crimes in the wildlife context can be exemplified by Paine’s (1999) discovery of a finely calibrated Reindeer Message System among the indigenous Sami in the Nordic countries. The animal targeted - its characteristics, sex, class, size, and the context in which it is stolen - conveys differential but mutually understood messages to the Sami herder whose reindeer was stolen.

On the other side of these relatively communicative acts are those tacit, opportunistic and presemiotic killings that have been retrospectively recast as political protest, with the initial intention of the offender remaining opaque. For example, the suicide and letter left by an illegal wolf hunter in Finland upon his conviction served as a communication of dissatisfaction against the Finnish Ministry of Agriculture and Forestry in 2010 (Ripatti, 2013). Taken individually, illegal killings may be sporadic petty crimes undertaken primarily as coping mechanisms by hunters in their everyday life (Scott, 1985). However, the generalisation of such activities into a pattern of resistance has become a political expression of the radicalisation of a disenfranchised social group that threatens the viability of wolf populations, the legitimacy of authority and the stability of the regime.

\section{HUNTING AS MAJORITY CULTURE}

The cultural importance of hunting as a life-supporting rural activity in the Nordic countries is underscored by folk stories and mythologies linked to social rituals that perpetuate today in Finland and Sweden, such as Valborg marking the driving away of predators from livestock grazing areas in spring by lighting bonfires (Tillhagen, 1987). Historical acceptance of hunting stemmed from a shared symbolic view of hunting between hunters and majority society (Peterson, 2004). This is evidenced in both institutional and public records. In the thirteenth and fourteenth centuries hunting acquired institutional authority through the introduction of legislation ("landskapslagar") in Sweden and Finland (Bisi and Kurki, 2008). 
Unlike in other parts of Europe where hunting was the purview of the elite, hunting of large carnivores was stipulated as civic duty (Nyrén, 2014) and authorities decreed that bounties on wolf kills could be used to pay state debts (Gothe, 1989). An archival search in 19th century in Finland yielded some 900 newspaper articles that openly endorsed the elimination of carnivores with an emphasis on wolves (Mykrä and Mykrä-Pohja, 2005).

While Finland was a part of Sweden from 1150-1809, historical sources illustrate a clash of these hunting cultures at a few points in their trajectory. Finnish intensive harvesting of wildlife resources and belief in no man's land ('Takamaa') on which game belonged to the hunter who pursued it began to be perceived by many Swedes as a threat to sustainability in the case of the Finnish immigrants in northern Sweden (Gothe, 1989). This contributed to hunting restrictions in the 17th and 19th centuries. Parts of the hunting community, including Swedes in the north, questioned the new legislation by stating that the word of the bible clearly gave man dominion over animals (Tillhagen, 1987). Recovering game populations contributed to extending the right to hunt from the crown and nobility, where it had resided for over a century, to land owners in 1789 and tenants some decades later (Eriksson, 2008). The powerful Swedish Hunting Association, established in 1830, was instrumental in forming a united opinion and a mouthpiece for Swedish hunting culture as well as being the body in charge of game management.

Into the 1900s, the annual moose hunt was celebrated as the pivotal event in many communities (Tillhagen, 1987; Eriksson, 2008). It typically commenced with a moose hunt mass in church and with a party in the community centre the Saturday before the first week of moose hunting season (Kyrkans Tidning, 2013). To this day in some parts of the Nordic countries, workplaces ceremoniously close for the event. In Finland, Metso Camps formed as game and hunting orientated camps for youth annually organised by the Finnish Hunters' Association. 


\section{HUNTING AS SUBCULTURE}

The shift of hunting from a majority subsistence practice to a subculture was largely precipitated by the interrelated processes of urbanisation and the rise of environmentalism (Giddens, 1994; Peterson et al., 2011). Subcultures have been established as elective social worlds among like-minded people on the one hand and formations that result from the exclusion of a group from majority society on the other (Squires, 2002). We contend this duality is critical to the self-understanding of the hunting culture. First, urbanisation contributed to a loss of rural holdover values pertaining to hunting as subsistence and as everyday practices of engaging with nature (Persson, 2010). Critical perspectives on modernity have argued the alienation of people from primary modes of food production left people “...confused and disconnected from the natural world.” (Bogliogli, 2009).

Second, the growing impact of non-anthropocentric ethics, which has increasingly induced a shift to seeing the countryside as post-productionist landscapes for recreation and conservation, has positioned modern hunting culture as an enterprise whose cultural practices have become in need of constant social legitimation. Following the influence of biocentrism and animal rights activism in the 20th century, the subculture has invited critiques by modern society based on moralistic critiques of killing wildlife (Nurse, 2013). Hunting is seen by many as a brutal anachronism that is morally hard to justify (Bogliogli, 2009; Peterson, 2004), as a self-perpetuating cycle of conserving and killing game for personal leisure and, finally, as a deviant subculture whose anthropocentric ethos and ideas of wildlife management conflict with the ideology of majority society (Brymer, 1991).

Meanwhile hunters have responded with a narrative that has turned inward and begun defining their subculture as exhibiting special bonds with nature. Within this narrative, alienation from the biotic system has been seen to represent a primary cause of 'illness' in 
modern humans. Hunting is seen as the cure as well as means of self-actualisation (Swan, 1995; Dizard, 2003). The demographic shift toward an urban hunting culture in the Nordic countries has strengthened the back to nature narrative as urbanites have sought relief from hectic city life in the form of a close experience with nature (Persson, 2010; Hansen et al., 2012). The subculture's role as a steward of the environment or 'healer' of the land has also been emphasised in discourses to legitimate hunting in modern society (Swan, 1995).

The back to nature and self-actualisation narrative has highlighted distinctions between hunters and majority society, facilitating an 'us' and 'them' orientation. Scholars have emphasised that this distinction to majority society has been characterised as both elective on the part of hunters and the result of oppression (e.g. Rogers, 1974; Jones, 1979; Brymer, 1991; Curcione, 1992; Pendleton, 1998; Eliason, 2003, Mischi, 2008; 2013). Brymer (1991) drew explicit links between the perpetuation of the hunting subculture, its differentiation from the majority society, an awareness of its own deviance in relation to dominant non-hunting norms and practices and indicated how this was conducive to a populist distrust of authority among modern hunters. As an extension of this distance to majority society, scholars have also observed how defensive localism and traditionalismoften framed in opposition to more changeable 'urban outsiders'-are perpetuated as norms, values and ideals in rural hunting communities through socialisation (Brymer, 1991; Forsyth and Marckese, 1993, Krange and Skogen, 2007; Mischi, 2008; 2013).

\subsection{A subculture under threat}

The environmentalist ethos grew teeth through European Union conservation policies in the 1980s and 1990s, which have placed hunters in a precarious situation in many parts of Europe (Nilsson Dahlström, 2003). In Finland and Sweden, the Habitats Directive in particular is perceived as a threat to livestock grazing, the safety of family and hunting dogs and small 
children because it means the re-entry of large carnivores in rural landscapes (Zimmerman et al., 2001; Bisi and Kurki, 2008; Sjölander-Lindqvist, 2008; 2009). As a corollary of this, the subculture has become marked by fears that an environmentalist agenda will infringe on hunting rights (Pyka et al., 2007; Bisi and Kurki, 2008). Following increased pressure and regulation on hunting in other parts of Europe, the Nordic hunters have become outright hostile to EU and governmental intervention in their lifestyles (Bisi and Kurki, 2008; Cinque et al., 2012). Non-hunting 'urban outsiders' or 'townsfolk' have increasingly been construed by hunters as being in alliance with scientists, politicians and natural resource managers in a hegemonic formation that is seen to systematically exclude hunting points of view on a fundamental level in the public debate on the rural landscape (Krange and Skogen, 2011).

In a critical perspective on this phenomenon, Mischi (2008; 2013) contends that the Europeanising process of environmental protection can be seen as the disciplinary appropriation of collective space, particularly among working class rural residents. This perspective finds substantial support in the Nordic context, where the most affluent have the most positive attitudes towards wolves (Lumiaro, 1997; Bisi and Kurki, 2008). Importantly, Euroskepticism has served as the seed for populist movements mobilised around hunting rights (Bisi et al., 2007). From these developments, forms of resistance have taken root within the subcultures toward the authority or objects symbolising the hegemonic formation around large carnivore reintroduction (Peterson, 2004; Mischi, 2008; 2013).

Furthermore, by turning their backs on policy and conservation commitments, hunters increasingly facilitate their positioning on the periphery of trending turns, such as the postproductionist rural landscape devoted to recreation and conservation. In this process, these hunters have been represented as bloodthirsty massacrers, and thrill-killers, and as backward rural leftovers and anti-environmentalists that preclude progress under the environmental movement (Sjölander-Lindqvist et al., 2010; Ekengren, 2012; Mischi, 2008; 2013). As a 
participant in South Savo, Finland, contended of the misconception of hunters during a public hearing on game management and the wolf crisis: "Conservation organisations loathe the word 'hunting'. They think it’s done for fun.” (Bisi and Kurki, 2008, p. 84).

\subsection{Radicalisation of the hunting subculture}

Antagonised by regulatory agencies on national and supranational levels, recalcitrant hunters have embarked on a radicalisation trajectory. This can be documented using McCauley and Moskalenko's (2008) radicalisation framework based on the concepts of superiority, injustice, distrust and vulnerability. Given the complexity of social conflicts, no one framework can offer an exhaustive explanation (Eidenson and Eidenson, 2003). What can be pronounced with some assurance, however, is that some form of interaction of these belief domains is necessary for radicalisation to occur (e.g. superiority is necessary in order for injustice to not be immobilising and debilitating). This is premised on the notion that pathways to radicalisation are mutually reinforcing (McCauley and Moskalenko, 2009).

The superiority concept can be identified, first, on the axis between humans and nonhumans. In the latter, hunters' strong anthropocentricism sees the relatively trivial interests of humans take priority over the vital interests of animals (Fjellström, 2002). On the second axis, between hunters and non-hunters, superiority emerges in how the hunting narrative contrasts the nature centred, integrity filled, pure, rural-pastoral lifestyle with environmentally disconnected 'urban outsiders'. Third, superiority is implied in rhetoric describing superiority of hunting rationalities on sustainable wildlife management over remote, shifting, political and elitist EU-based ecological knowledge (Mischi, 2013). Finally, there has been a potent fear within the subculture of losing game populations to predation by large carnivores (Pyka et al., 2007; Bisi and Kurki, 2008). Bogliogli (2009) demonstrates 
that in the hierarchy of wildlife, hunters position game animals above carnivores, which fundamentally challenge the human role in the cultural economy of killing.

The hunting subculture focuses on perceived extravagance of large carnivore research and inequitable impacts of carnivores on rural lifestyles when articulating injustice. Researching, tracking and helicopter relocation of individual wolves have been juxtaposed with the inability to get a helicopter ambulance for 'granny' in rural areas (Bisi and Kurki, 2008). Although such events may be relatively rare, their rhetorical power has arguably been harnessed to magnify perceptions of injustice by hunters. Perceived injustice, such as the alleged prioritisation of environmentalist goals including the EU-derived scientific calculation of favourable conservation status for wolves has also resulted in a more focused and political articulation of hunting, livestock grazing and foraging the woods for berries and mushrooms as components of a traditional pastoral 'rural lifestyle' that is rendered impossible in many regions (Pyka et al., 2007; Sjölander-Lindqvist, 2008; 2009). The injustice of new regulation that infringes on customary rights of access has been demonstrated to be a key factor in mobilising historical hunting subcultures (Thompson, 1975; Forsyth and Marckese, 1993; Manning, 1993; Muth and Bowe, 1998).

Distrust of the regime has centred both on EU level agencies, and concerns about cooptation of hunting organisations by the state. The average hunter began viewing the Swedish Hunting Association's governmental affiliation with some scepticism in the early 1900s. As a reaction to this the more radical organisation, Hunters' National Association, was formed as independent organisation in 1938. The new association allowed publication of regime-critical opinions and editorials from hunters' perspectives. For hunters, suspicions of the Swedish Hunting Association's close ties with the regime were confirmed in 2012 when the association was required to support unpopular carnivore politics in the countryside in order to retain government funding. This change was followed by 25,000 members leaving the 
organisation and joining the Hunters National Association, many of whom felt the Swedish Hunting Association was in collusion with the state (Cederqvist, 2013).

Distrust in the authorities presently tasked with wolf management is evident both in Sweden and Finland. Studies have indicated a lack of trust impeding cooperation among authorities and that hunters, especially in Finland, where hunters purportedly experience a climate of secrecy around which governing bodies coordinate and manage the wolf (Bisi et al., 2007). The distrust is indicated by beliefs of cover-ups and conspiracies related primarily to wolf numbers, locations, feeding, origins and genetics. Conspiracies have come to constitute powerful counter-narratives of wolf ecology in many hunting circles in both Finland and Sweden (see for example Granlund, 2014, on illegitimate wolf-dog hybrids).

Hunters express the vulnerability concept in the radicalisation of the subculture in narratives about losing their role as a steward of the environment, the demise of lifestyles and traditional ways of hunting with dogs to the presence of wolves, which is relatively unique to Scandinavia. There is a particular fear concerning the threat to the much valued and equally unique sheep husbandry practices (transhumance) of the Nordic countries (Skogen et al., 2008). The loss of these husbandry practices can moreover be said to be situated on a broader terrain of rural vulnerability, following the depopulation and destocking of the countryside.

The loss of cultural heritage interacts with the loss of decision-making power to create an even deeper sense of vulnerability (Bisi et al., 2007). Notably, the constituency for game and wildlife management in Sweden was widened from the Swedish Hunting Association to twenty-one game management delegations comprised by about fifteen delegates each, including representatives from nature environmentalist NGOs (Parliament Decree 2009:1474). In Finland, hunting organisations played an even stronger role in game management decisions prior to accession into the EU than did its Swedish counterparts, causing Finnish hunters to experience a severe loss of power (Pellikka, 2005). 


\section{HUNTING CULTURE AS COUNTERPUBLIC}

Following McCauley and Moskalenko’s (2008) framework, a counterpublic may materialise as a subculture goes from being a mere differentiation of majority culture toward constituting a political reaction to the present situation in the public. The critical contention is that the concept of the public is invariably related to power, exclusion, and control (Meehan, 1995; Wimmer, 2005). This is one dimension in which counterpublic distinguishes itself from the constructs of subculture, counterculture and various other social movements. Furthermore, in order to understand the hunting counterpublic, we first define the public. Warner (2005) in his essay collection 'Publics and Counterpublics' (2005) contends:

"To address a public or to think of oneself as belonging to a public is to be a certain kind of person, $[\ldots]$ to be motivated by a certain normative horizon, and to speak within a certain language ideology.” (Warner, 2005, p. 10).

The rise of the counterpublic, moreover, is contingent on three components that can collectively be understood as constituting a crisis of the public sphere (Negt and Kluge, 1972; Fenton and Downey, 2003). First, in this context the public is perceived to be colonised by an EU environmentalist agenda that leaves no room for alternative rationalities. Critics of Habermas' ideal of the public sphere have observed this predicament in counterpublic theory by positing that the public is marred by exclusion of subordinate groups in society (Negt and Kluge, 1972; Fraser, 1990). This denotes the first prerequisite to the rise of counterpublics. The second prerequisite is that the public sphere has been colonised by modern scientific rationality of states and institutions ('the system') and can no longer serve as a sphere for rational-critical and intersubjective dialogue that can inform decision making (Habermas, 
1962; Hess, 2010). Third, distrust in the system rises in times of legitimation crises, in our case study stemming from failure in accommodating the perspectives of hunters in wolf reintroduction decisions. When these conditions are met, a response in the form of a counterpublic may emerge to contest the premises of the public by constituting an alternate public formation (Eckert and Chadha, 2013).

The term counterpublic (Gegenöffentlichkeit) first appeared in Negt and Kluge’s Public Sphere and Experience (1972) as an alternative discursive site to Habermas' public sphere. A counterpublic sphere was seen as a deterritoralised rallying point comprising the 'leftover' interests by dominant society; in other words, disenfranchised, hidden or inarticulated voices in a public that is dominated by one narrow type of rationality. In the 1970s, Negt and Kluge (1972) construed this parallel sphere as a proletarian public sphere characterised by a defensive stance toward the rest of society and its push for progress. It was then mobilised on the basis of concrete and marginalised voices in the bourgeois public. The notion of counterpublics has since promulgated onto a broader terrain of disenfranchised social groups that can publicise oppositional interpretations of their interests, needs and identities in times of crisis of the public sphere (Fraser, 1990; Asen, 2000; Warner, 2005).

Following Negt and Kluge’s (1972) original formulation, counterpublics often exhibit distrust of grand narratives including progress and the dominant public ideology. Popular peasant counterpublics often broadcast a valorisation of the local and rural (Fraser, 1990; DeLuca, 1999). The hunting counterpublics have a strong element of conservatism related to a pastoral rural lifestyle. The designation of counter, furthermore, implies a contestatory formulation of social reality in which goals, norms and moral ideals contradict those of the dominant narrative. In the environmental movement of modernity in which a dominant voice in the public subscribes to ideals of 'rewilding', 'conservation' and 'ecosystem health', the hunting counterpublics has adopted 'stewardship', 'management' and 'tradition' as counter- 
buzzwords in its agenda. The counterpublics have also evoked counter-knowledge with their own set of credentialed ecologists who criticise, reappraise or otherwise contest the favourable conservation status of wolves (see for example, wolf expert Olof Liberg). Taking Ferguson's (2010) postulate that a counterpublic is able to witness itself in space, the assembling of the hunting counterpublics began to materialise in hunting associations, online forums, facebook groups and across a range of symbolic rural meeting places in Sweden and Finland. Entirely new yet concrete spaces emerged as sites of counterpolitics including weblogs, political parties and independent media channels. While this materiality of counterpublic is essential, scholars caution against reductionism of counterpublic to fixed categories of people, places and topics (Porrovecchio, 2007). This means that the hunting counterpublics can materialise in the physical assembling of a public, and that the circulation of members in and out of the counterpublics is essential.

\subsection{Counter politics of the hunting counterpublic}

Negt and Kluge (1972) contended establishment of a critical rhetoric that could reinvent a promise of community among subordinate groups, based on synthetic and syncretistic images was key to counterpublic success. While primarily mobilised on the basis of dissatisfaction surrounding wolf reintroduction, the hunting counterpublics in Finland and Sweden can best be understood as opportunistic alliances among related marginalised causes with the aim of establishing a more powerful coalition for political change (Squires, 2002; Woods, 2003; Fenton and Downey, 2010; Hess, 2010; Sziarto and Leitner, 2010). Many scholars have demonstrated that an important coalition for hunting issues to join is 'politics of the rural' or an agrarianist ideology. In this ideology, a pastoral rural identity under threat serves as a catalyst for mobilisation across several interest groups (Woods, 2003; Krange and Skogen, 
2007; Mischi, 2008). Woods (2003) contended of the opposition to the Hunting Act in the UK:

\begin{abstract}
"The single issue of hunting could not mobilise sufficient public support to successfully resist legislation to ban the sport, but positioning hunting as fundamental to rural life-and consequently positioning a ban on hunting as an attack on rural identity—could.” (p. 316)
\end{abstract}

Although Woods (2003) concedes that a coalition on 'politics of the rural' is fraught with tensions following the existence of what are in fact distinct ruralisms, he argues convincingly that by discursively connecting rural problems as a multi-issue uniting force, a continuity of existence and the legitimation of activism in service of these issues can be achieved. In the hunting counterpublics, juxtaposing the amount of resources devoted to wolf reintroduction to scant economic investment in the depopulating countryside provides a potent example of the government prioritising the wishes of an urban majority society at the expense of a deteriorating rural population (Krange and Skogen, 2007; Ekengren, 2012). This perception has been evidenced in a range of polls and debates; in central Finland a resident revealed during a public forum debate for game management how: “[authorities and urban residents] are purposely devastating the countryside” (Bisi and Kurki, 2008, p. 96).

Ekengren (2012) found that some environmental groups believe hunting counterpublics work to rhetorically construct a rural and urban divide. While it is beyond the scope of this paper to ascertain the accuracy of this charge, the rural predicament now provides the premise for an increasing number of political initiatives. Those expressly articulating the devastation of the countryside in concert with wolf management issues include the Countryside Party, the Nature Democrats and Peoples' Campaign for a New 
Predator Policy in Sweden and the high profile Centre Party and populist True Finns in Finland. The counterpublic has also forged alliances with transhumance livestock farmers who perceive cultural and livelihood threats from increasing wolf populations. At other times, the counterpublic has prima facie adopted a 'vicarious grievance' (Schmid, 2013) through seeking solidarity with the indigenous Sami in Laponia whose reindeer herding is especially vulnerable to increasing wolf populations (Beach, 2004; Bisi and Kurki, 2008).

Sites for gathering forces and establishing critical rhetoric have helped the hunting counterpublics develop a strong media presence and supported political petitioning to the EU and to national authorities (Bisi et al., 2007). Mansbridge (1996) and Asen (2000) suggest the counterpublic sphere serves as a site of withdrawal for reformulating interpretations and identities away from the public eye. In line with Negt and Kluge (1972)'s concept of Erfahrung, the reformulation that takes place in these settings of withdrawal often uses common sense and experience in formulating counter-narratives to contest the expert accounts used by decision makers (Carpignano et al., 1993; Asen 2000).

Importantly for the radicalisation trajectory, however, the hunting counterpublics can also serve as bases for agitational activity (Haran, 2013). To illustrate this, the Swedish Hunters Association (SJF) and the Hunters' National Association of Sweden comprise key settings for the counterpublic in Sweden, while at the same time provide a discursive platform for the circulation of radical sentiments including the outright endorsement of extreme tactics. Members' questioning of wolf reintroduction and self-professed complicity in not reporting illegal hunting activity (Pyka et al., 2007; Peltola et al., 2013) arguably undercuts the legitimacy of the regime in a way that pushes the counterpublic toward more radical forms of resistance. Taken further, hunting associations may have publically distanced themselves from all forms of illegality, but continue to contest the premises of policy in a way that achieves a climate for illegal hunting discourses. This is particularly problematic as 
when hunting magazines spur on hatred for wolves (Sjölander-Lindqvist et al., 2010) and when persons in positions of power, including local law enforcement, hunting license course instructors and staff editorials and blogs with the Swedish Hunting Association, endorse radical physical tactics as means of denunciating wolf reintroduction (see, for example: Pott, 2011; Glöersen, 2013). In this way, hunting associations provide breeding grounds for increasingly agitational activity while simultaneously reproducing a safe official discourse at the level of the public. Ekengren (2012) has additionally suggested that while the associations on the whole remain as publically neutral as possible, more militant organisations have emerged on the sidelines in recent years, providing a forum for communication and behaviour not sanctioned in formal associations (see figure 1 of a member’s tattoo 'Våga Vägra Varg' meaning 'Dare to Refuse the Wolf', the slogan of a radical anti-wolf group).

\section{[INSERT FIGURE ONE HERE]}

Scholarship on social movements and civil disobedience suggests members of the counterpublics are often perceived as departing from social norms in subversive ways, thereby increasing the social distance between them and the majority society (Jacobsson and Lindblom, 2012; Ólafsson, 2012). As an example of this, some hunters have responded to wolf reintroduction by boycotting the practice of tracking injured wildlife. Police authorities previously relied on the goodwill and skill of hunters to euthanize wildlife that were injured, typically by vehicle traffic. This voluntary agreement required hunters to be available 24 hours a day and constituted an act of civil courage. Hunters coordinating this practice went on strike several times in the past decade, most famously through the Swedish Dala Revolt in 2004-2005 (Sjölander-Lindqvist, 2011). In 2013 Svenljungagruppen, the current leader of the initiative in Sweden, halted the boycott upon being told of an upper limit of 180 would be imposed on the wolf population. However, following EU appeals of this and failure on the part of politicians to fulfil their promise, the boycott resumed and grew worse. This 
development is significant, because it required hunters to suspend their ethics concerning the humane killing of wildlife, thus risking strong public reactions.

In summary, this section has shown that sites of reformulation and the establishment of a critical rhetoric that applies across social groups feature heavily in the radicalisation of the hunting counterpublics. The uniting of heterogeneous ruralities through discursive interconnection does raise questions concerning the directionality of the counterpublics. Krange and Skogen (2011) suggested there is a tendency to portray the practices of hunting movements as more coherent and directional than they are. This contention coheres with counterpublic scholarship which has emphasised the critical, anti-institutional and alternative discursive nature of counterpublics more so than their pursuit of clearly defined objectives or list of bargaining points (Wimmer, 2005). In the case of the Nordic hunting counterpublics, the polemical wolf reintroduction has expanded to comprise the survival of the countryside at large, and serves as a manifestation of discontentment surrounding perceived exclusion of rural publics from the public agenda.

\section{BEYOND COUNTERPUBLIC: TOWARD ILLEGAL HUNTING}

Most members of the hunting counterpublics challenge the regulatory agencies while remaining law-abiding citizens. Practices of resistance against wolf reintroduction have gradually become more radical, including threats and violence and, as illustrated, there is increasing support for norm-violating resistance like the foregoing of hunting ethic through

the boycott of game management duties. This raises questions about what characterises the transition from legal to illegal resistance on the trajectory of radicalisation?

In summation of the radicalisation trajectory thus far, we can state that stigmatisation and misrecognition of hunters' identities by media and members of a Europeanised public has weakened social bonds between the hunting subculture and majority society. Social control 
theory (Hirschi, 1969) suggested attachment, involvement, commitment and shared belief in the form of social bonds help prevent crime, which is precipitated in large part due to the weakening of the regard for and attachment to societal norms (Hirschi, 1969). Fenton and Downey (2003) press that the weakening of social bonds above all stems from a crisis of legitimacy and loss of trust in those institutions established in the public sphere, which has demonstrably occurred in the case of the Nordic hunters. Weakened social bonds precipitates delinquency and crime in Hirschi’s criminological theory.

We see three main recourses available to the counterpublics in the final stages of their trajectory. We believe these options can be generalised to a degree for other contentious counterpublics. First, they become successful in challenging the norms and values of the dominant narrative. Bringing about social change that is accepted by society, the counterpublics are no longer counter but assimilate into the public for all intents and purposes. This for example took place in the case of the equal rights counterpublic in the 20th century, which saw contestatory norms and ideals concerning women's suffrage and human rights become part of the public and moral order. In our case this would require compromising the environmentalist ethos to the extent that the hunting counterpublics achieve a substantially revised conservation policy bringing hunting interests and rural livelihoods to the forefront of politics and economic investment. Wolves would lose their unequivocal protected status and licensed hunting would be reinstated. Hunters would regain influence over wildlife management, in particular, of large carnivores in their landscapes.

In the second recourse, the counterpublics are unsuccessful in achieving recognition and are silenced to the degree that radical values and behaviours gradually disappear. Policy remains largely unchanged and mere pockets of resistance exist without political impetus or a substantial subcultural identity as base from which to mobilise counterpublic practices. This can be understood as part of the dominant society's tactic to simply make the counterpublic 
go away by not 'negotiating with terrorists'. More rarely the state may impose bans and greater sanctions on hunting rights in an effort to actively deter opposition. Such a strategy has received mixed success in those cases where the counterpublic is well-established, as is arguably the case for the hunting counterpublics across Nordic countries (Bisi et al., 2007). Finding increasing support for its cause, it may opt for defiance in the face of harsher stigmatisation and injustice as was the case with the similarly socio-politically marginalised poaching gangs in medieval Britain (von Essen et al., 2014; Jones, 1979).

The third route into which a counterpublic may be forced has more serious implications for society. Despite practicing increasingly agitational activities to further its cause, the political order may reject the counterpublic's narrative and their need for recognition. Rather than regressing to a subculture, hunters may choose to cease operating within the political parameters of the counterpublic enterprise. In short, they terminate dialogue with the rest of society through formal political channels, including political motions, writing editorials, joining rallies and organising boycotts. At this point individuals abandon the premises of their public and may be pushed into a situation in which they break the law to protect their lifestyles. While originating as sporadic, perhaps private ventures, illegal hunting quickly gets sustained in a social context of support where such resistance is legitimate (Scott, 1985; Jacoby, 2001). Formal organisations need not support the conduct in large part because dense informal social networks within the hunting community, now including discursive spaces for hunters on the internet, suffice (Scott, 1985; Rytterstedt, 2013) which has been demonstrated in the Nordic hunting context.

One subset of the third route involves illegal hunting as open defiance against the regime. Although it may take place concurrently with everyday forms of resistance, illegal hunting as public insubordination against the regime sits in stark contrast to the covert 'shoot, shovel, and shut up’ practice. Scott (1985) wrote that such instances of open defiance often 
signify that more covert forms of resistance are failing. Resistance thus becomes less about material gains and coping and more about symbolic protest. Illegal hunting becomes a political message crime by transgressing private aims to include counterpublic goals of legitimating alternative social change, ideas or progress (Passas, 1986). This has taken place within a context of resistance against EU conservation directives in other parts of Europe; in France for example the radicalisation of hunters culminated in the killing of 1,000 birds and the destroying of natural park facilities as a response to new EU conservation legislation (Mischi, 2008; 2013). In the Global South, the killing and public dumping of elephants without harvesting their ivory tusks sends an analogous message over unjust policy (Holmes, 2007). In eastern Finland where trust in authorities is severely degraded (Bisi et al., 2007) hunters who illegally kill wolves have thus begun to speak openly about the killings, the number, the individuals and their motives as manifestation of frustration toward the regime. At present, hunters are even raising collective funds to support their peers accused of illegal hunting of wolves (Pott, 2014). These acts are relatively straightforward to resolve as political because they operate in public (or counterpublic) channels and are communicative.

Nevertheless, the more prevalent covert forms of illegal hunting have arguably managed to cumulatively leave a larger political imprint on majority society. At one level they are also communicative, albeit in an indirect and disguised manner. Although the individual crimes remain hidden the generalised pattern of resistance, and the aggregate consequences of wolf killing, has frequently been deployed by hunters as a strategy of open defiance. Editorials and articles by the hunting associations in Sweden frame the rise of illegal hunting as a warning to majority society that this sort of 'local' management of wolves, citing its prevalence in Finland, will be what hunters resort to if there is no national management plans for wolves (Moilanen, 2014). At present, a third of wolf mortality is estimated by be induced by illegal killing in Sweden, with higher numbers in Finland (Liberg 
et al., 2012). Predicated upon the premise that hunting now more than ever needs to carefully negotiate its social legitimacy in society through the creation of an ethical space shared with non-hunters (Peterson, 2004), the practice of illegal hunting threatens to constrain this shared ethical space. In so doing it risks increasing the distance between the counterpublics and majority society, widening the fault lines of the rural-urban and between the European Union and residents of its member states.

\subsection{Situating the radicalisation trajectory}

Radicalisation of one party cannot be fully articulated without an understanding of the shifting social milieu in which the group exists. McCauley and Moskalenko (2009) raise the important point that the polarisation process in society tends to radicalise both sides. A cursory look at the situation may well support this; the conservation movement has radicalised into increasingly extreme philosophies of biocentrism and radical ecology and actions (e.g., ecoterrorism, publications devoted to spreading the 'gospel of conservation') from once having shared an anthropocentric ideology with the hunting community. Indeed the killing of large carnivores was demonstrably part of a cultural heritage much older than any ideology that proscribes the killing of carnivores in Finland and Sweden.

However, the declaration that there are “...people living today who grew up in a world where they were paid by the state through bounties to exterminate these species [...] now would be jailed for doing the same thing.” (Linnell, 2013, p. 14) is a somewhat remiss and overly jarring characterization of events. The killing of wolves may have constituted a historically accepted practice, but contemporary Nordic hunters, particularly in Sweden, lost direct experience with wolves toward the end of the 1800s, when few or no wolves were south of the river Ljusnan in the north. Hunting wolves as a new game species, therefore, has merited special training programmes (Sjölander-Lindqvist et al., 2010). Although some rural 
hunters may associate themselves with an old hunting culture more so than the new influx of urban hunters, it is difficult to dismiss the crime as people doing 'what we always done', when the hunters in question have never experienced wolf hunting or law-breaking until wolves re-colonised under recent EU protection. Wolf killing, moreover, is thus less a direct continuity of lifestyle and more an atavistic phenomenon in contemporary society.

Furthermore, the Nordic hunters appear to be radicalizing along three dimensions. The first dimension pertains to action, and can be identified as the change in the character of resistance practices. It is imperative to note that mounting resistance toward hunting and wildlife regulation is a new practice in the Nordic countries. This extends both to poaching, which historically occurred on a very limited scale compared to other countries, and the mobilisation of resistance toward regulatory agencies in the general sense. In his dissertation on hunting rights in Sweden, Nyrén (2012) argues that unlike the situation in Britain where popular resistance was raised by 'social bandits' against the ruling elite, the public was too subordinate to the decrees of the elite and church to mobilise resistance for change. Today there has not only been an increased mobilisation of militant initiatives, associations and protests, but within these resistance strategies has occurred a radicalisation whereby the disenfranchised are turning to personal threats against civil servants and media figures and sabotage like tyre-slashing and failing to euthanize traffic-injured wildlife.

The second dimension of radicalisation pertains to a fundamentalist hardening of beliefs and rhetoric. There has been a widened dimension of 'hatred' toward and 'othering' of the state, the EU and urban residents in hunters' collective mind-set. As an extension of this, hunters have ascribed increasingly malign intent on the part of authorities and urban residents toward the hunting culture. Whether a genuine belief or a rhetorical point, hunters were also found in extension with this distrust to increasingly subscribe to an inexorable logic of worst- 
case scenarios, e.g. 'the purposive devastation of the countryside' (Bisi and Kurki, 2008) and the eradication of cherished cultural heritage practices.

The third dimension of radicalisation draws from Demant et al.'s (2008) definition of radicalisation constituting "a process of de-legitimitation, a process of in which confidence in the system decreases and the individual retreats further and further into his or her own group, because he or she no longer feels part of society” (p. 19-20). As illustrated, hunters have increased isolation from and distance to the rest of society by turning inward to a personally relevant collective with its own set of rules and norms in a kind of Wild West scenario. This occurs concurrently with and is mutually enforcing of radicalisation in the action and belief domains. This is most apparent in the step beyond the counterpublic, signifying the end of dialogue. Severing social bonds with society and being increasingly placed under the totalizing influence of the collective, moreover, renders a group exceedingly vulnerable to additional pathways to radicalisation (McCauley and Mosalenko, 2009).

\section{IMPLICATIONS OF THE COUNTEPUBLIC}

While the hunting counterpublics have achieved some success and thus may arguably follow the aforementioned trajectory one, the increase in illegal hunting suggests an alternative interpretation. The hunting counterpublics in Finland and Sweden have on a practical level been somewhat productive; they have indisputably yielded material concessions on the part of authorities in the past decade, including a temporary licensed wolf hunt (thereby violating EU legislation), amendments of the $\S 28$ in the Swedish Hunting Decree which has allowed certain protective hunting measures against wolves attacking one's property, and the creation of County Game Management Delegations in Sweden in a bid to regionalise conservation practice in order gain favour with the countryside and with hunters (Matti and Sandström, 2013) 
The territoriality of the counterpublics to a pastoral countryside, however socially constructed, can be said to represent an attempt at the re-appropriation of space colonised by a remote EU parliament. On an individual level the counterpublics have offered some solidarity in a shared experience of disenfranchisement among hunters and rural residents. In the Hegelian notion of recognition, membership in this counterpublic can be read as a way for members to constitute and transform their identities into something productive, positive and collective that they are able to publicise in a counterpublic sphere (Honneth, 1995; Warner, 2005). On a societal level of democracy, Negt and Kluge (1972) professed the productive possibilities of counterpublics as political initiatives. Since then they have been seen as vital impulses to democratisation (DeLuca, 1999; Fenton and Downey, 2010), as expansions of discursive space in society (Asen, 2000) and as potential correctives and innovators to the political order (Wimmer, 2005). This sets counterpublic apart from subcultures and countercultures in allowing members to form part of a public sphere of their own making that grants them a (counter) form of authenticity as citizens rather than mere membership.

Krange and Skogen (2011) used the Hammertown mechanism as a way to explain how hunting movements mobilised in opposition to large carnivore conservation in the Nordic countries were successful on the level of achieving a certain autonomy through its subculture, but purchased this at the considerable cost of further marginalisation of its members by way of blocking conventional political access. In the case of illegal hunting as the extremist outcome of an unsuccessful counterpublic, the illegal nature of the practice means that members literally place themselves outside of the law, outside of and counter to dominant social norms, and outside of (even counter-) public parameters.

Responses to this sort of social exclusion often bear a family resemblance to one another. A recurrent theme includes society having turned their back on them, so they turn their back on society to constitute a personally relevant collective for moralisation. This has 
been conceptualised in the case of immigrant (see, for example, the work of Charles Taylor, 1994) and youth subcultures, which do not feel bound by the will of society and resort to criminal activity. These parallel spheres become breeding grounds for apathy and cynicism, and occasionally activism (Fenton and Downey, 2003). Social exclusion does not always generate violent crime but frequently precipitates the legitimisation of lesser forms of misconduct and petty acts of resistance toward the regime, such as tax evasion, not registering to vote in elections, and not relying on state services e.g. police, hospital.

From a state-centric historical perspective it is thus imperative that counterpublics and populist movements be met with a great degree of attentiveness by majority society. In the hunting counterpublics’ promise of a community based on marginalised but also superior, elitist and traditional interests, it has offered pride as shared solidarity instead of shame as an escape route. This finds parallels in the rise of fascist and extremist movements like neonazism, but also terrorism (Scheff and Retzinger, 1994; Honneth, 1995). Such radicalisation highlights the importance of granting the hunting counterpublics recognition as political actors and as citizens. Significantly, this perspective construes resistance in Hegelian terms of moral feelings of indignation and violations of certain accustomed expectations regarding recognition rather than as something stemming simply from objective inequalities in material opportunities (McNay, 2008). This point is important to an understanding of counterpublic theory, which also distinguishes a counterpublic from a subculture or a counterculture, because the latter go about their business privately and seek material gain respectively. While counterpublics have an interest in material goals, Loehwing and Motter (2009) caution that we should not risk a preoccupation with how a multiplicity of competing publics struggle for political power in society. Doing this would reduce the democratic ideal of popular sovereignty to a matter of achieving competing political interests in society. It is rather about creating the space for multiple rationalities to be expressed and evaluated with regard to their 
validity. This, moreover, must take place in a public debate which one can enter on free and equal terms. This means that granting material concessions to hunters as a homogeneous interest group, for example by giving them a narrowly pre-defined role to play in Game Management Delegations, will demonstrably not solve the problem. Rather the materiality of the conflict must be addressed alongside of immaterial drivers, including lack of recognition.

Less radical hunters point to licensed hunting of wolves as a potential way forward. This policy would accomplish three things: first, it would re-grant hunters a continuity of customary hunting tradition by restoring the wolf to a game species; second, licensed hunting of genetically unimportant wolves, troublesome wolves or geographically misplaced wolves would give hunters the chance to contribute to the realisation of the common goal of ensuring the health of the population; third, provided that hunters and their organisations be given ownership of the planning and organisation of the license hunts they may experience recognition of their internal narrative that emphasises hunters as stewards of the environment.

\section{CONCLUSION}

The radicalisation of the hunting public into illegal hunters in Sweden and Finland included three junctures in a trajectory from majority culture to subculture to counterpublic and beyond. The external processes that contributed to this radicalisation including the rise of a environmentalist ethos, 'Europeanisation' of rural space, and a crisis of legitimacy of the public sphere. By construing counterpublic as a politicised subculture the paper addressed the counterpublic dilemma of circularity. Namely, that a public has to exist in some form with pre-existing channels or circulation in order to be addressed, yet comes into existence through being addressed. Failing to challenge the dominant public ethos or bringing about policy change, we theorised that hunters in Finland and Sweden who illegally kill wolves have been radicalised beyond their respective counterpublic arenas. This was conceptualised in two 
ways: as tacit and pre-political everyday form of resistance that becomes politicised upon its communication to the public and, two, as open defiance with the intention of sending a message to authorities. The former is the most prevalent form and is communicated as a generalised development. Increasing public support may however suggest that outright defiance, or 'message crimes', may become more common in the future.

Finally, we took a critical look at radicalisation as a potential misnomer. This was premised on the observation that everyday resistance practices reflect individuals doing more or less what they have always done and what were once legally, culturally and morally embedded practices in majority society. At present, most studies within conservation criminology have dismissed illegal hunters as deviants, criminals and extremists when they should situate the phenomenon within the changing ideological contours of society that label them so. Nevertheless, we caution against abandoning the use of radicalisation in the case of hunters, as this risks romanticising increasingly violent and illegal behaviour.

\section{Acknowledgements}

This work was supported by The Swedish Research Council Formas' annual open call (2012) for applications for research and development project grants, and the Gunnar and Lillian Nicholson endowment. Awarded to H.P.H. and co-applicant H.N.K. for the project: Confronting challenges to political legitimacy of the natural resource management regulatory regime in Sweden—the case of illegal hunting [grant numbers 2012-7896-23062-36].

\section{References}

Arnold, D. 1970. The Sociology of Subcultures. Glendessary Press. University of Michigan

Asen, R. 2000. Seeking the 'Counter' in Counterpublics. Communication Theory 10 (4), pp. 424-446. 
Beach, H. 2004. Political Ecology in Swedish Saamiland. In Anderson, D. Nuttall, M. Cultivating Arctic Landscapes: Knowing and Managing Animals in the Circumpolar North. Berghahn Books: Oxford

Bisi, J., Kurki, S., Svensberg, M., Liukkonen, T. 2007. Human Dimensions of Wolf conflicts in Finland. European Journal of Wildlife Research, 53, pp. 304-314

Bisi, J., Kurki. S. 2008. The wolf debate in Finland expectations and objectives for the management of the wolf population at regional and national level. Seinäjoki, University of Helsinki.

Bogliogli, M. 2009. A Matter of Life and Death: Hunting in Contemporary Vermont. Amherst. University of Massachusetts Press

Brymer, R. 1991. The emergence and maintenance of a deviant sub-culture: The case of hunting/poaching subculture. Anthropologica, 33, pp. 177-194.

Carpignano, P., Anderson, R., Aronowitz, S., DiFazio, W. 1993. Chatter in the Age of Electronic Reproduction: Talk Television and the 'Public Mind. In Robbins, B. Editor, 1993. The Phantom Public Sphere. Minneapolis: University of Minnesota Press.

Cinque, S., Sjölander-Lindqvist, A. Bendz, A. 2012. Värmlänningarna och rovdjursförvaltningen. In Nilsson, L. Aronsson, L. Norell, P. Editors, 2012. Värmländska landskap. Cerut, Karlstads universitet och SOM-institutet, Göteborgs universitet. Karlstad University Press

Curcione, N. 1992. Deviance as delight: Party-boat poaching in southern California. Deviant Behavior, 13, pp. 33-57 
DeLuca, K. M. 1999. Image Politics: The New Rhetoric of Environmental Activism. New York: The Guilford Press

Demant, F., Slootman, M., Buijs, F., Tillie, J. 2008. Decline and Disengagement: An Analysis of Processes of Deradicalisation. IMES Reports Series. Amsterdam.

Dizard, J. E. 2003. Mortal stakes: hunters and hunting in contemporary America. University of Massachusetts Press, Boston

Duenckmann, F. 2010. The village in the mind: Applying Q-methodology to re-constructing constructions of rurality. Journal of Rural Studies, 26 (3), pp. 284-295

Cederqvist, K.O 2013. Förbundet har tappat 25000 medlemmar. Dagbladet. Published 201303-13

Retrieved at: http://www.dagbladet.se/allmant/medelpad/forbundet-har-tappat-25-000$\underline{\text { medlemmar }}$

Eckert, S. Chadha, K. 2013. Muslim bloggers in Germany: an emerging counterpublic. Media Culture Society, 35 (8), pp. 926-242

Eidelson, R.J. Eidelson, J.L. 2003. Dangerous ideas. Five beliefs that propel groups toward conflict. American Psychologist. 58, (3), pp. 182-92.

Ekengren, A.M. 2012. The Wolf Debate and Political Cleavages: Interest mobilisation in Sweden. Statsvetenskaplig Tidskrift, 114 (4).

Eliason, S. 2003. Illegal hunting and angling: The neutralization of wildlife law violations. Journal of Society and Animals, 11, pp. 225-243. 
Ericsson, G., Sandström, C. Kagervall, A., Johansson, M. 2012. Om svenskars inställning till jakt och vargjakt. Rapport 8. Department of Wildlife, Fish and Environmental Studies. Swedish University of Agricultural Sciences

Eriksson, J. 2008. Älghistoria på Kornet. Sörmlandsbygden.

European Commission on the Environment 1992. The Habitats Directive. Council Directive 92/43/EEC

Fenton, N., Downey, J. 2003. Counter Public Spheres and Global Modernity. Javnost-The Public 10 (1).

Ferguson, K. 2010. Anarchist Counterpublics. New Political Science, 32 (2), pp. 193-214

Fjellström, R. 2002. Specifying Speciesism. Environmental Values, 11 (1), pp. 63-74

Forsyth, C., Marckese, T. A. 1993. Folk outlaws: Vocabularies of motives. International Review of Modern Sociology, 23(1), pp. 17-31.

Fraser, N. 1990. Rethinking the Public Sphere: A Contribution to the Critique of Actually Existing Democracy. Social Text, 25/26, pp. 56-80

Giddens, A. 1994. Beyond Left and Right: the Future of Radical Politics. Cambridge : Polity.

Gothe, R. 1989 [1942]. Hassela-finnarna: ett oromantiserat tvärsnitt genom "livet i finnskogarna" : kulturhistoriska undersökningar från en norrländsk finnbygd under 1600och 1700-talen. Sundsvall: Sundsvalls kulturnämnd.

Glöersen, G. 2013. Vargjakt i vinter, ja eller nej? Jägarbloggen. Svenska Jägareförbundet. Published 2013-08-29

Retrieved at: www.blogg.jagareforbundet.se/2013/08/29/vargjakt-i-vinter-ja-eller-nej/ 
Granlund, K. 2013. Från gråvarg till hybrid. Vart försvann den äkta gråvargen? Kommer våra barn att minnas oss som den generation, som i sin naturvårdsfanatism utrotade den äkta vargen? Lestijärvi Finland

Habermas, J. 1962. The Structural Transformation of the Public Sphere: An Inquiry into a Category of Bourgeois Society. Translated by Burger, T., Lawrence, F. Cambridge: Polity Press

Hansen, H. P., Peterson, M.N., Jensen, C. 2012. Demographic transition among hunters: a temporal analysis of hunter recruitment dedication and motives in Denmark. Wildlife Research 39(5), pp. 446-451.

Haran, J. 2013. The UK Hybrid Embryo Controversy: Delegitimising Counterpublics. Science as Culture. 22 (4), pp. 567-588

Hess, D. J. 2010. To tell the truth: on scientific counterpublics. Public Understanding of Science 20(5), pp. 627-641.

Hirschi, T. 1969. Causes of Delinquency. Berkeley: University of California Press.

Holmberg, S., Weibull, L. 2011. Förtroendekurvorna pekar uppåt. In Holmberg, S and Weibull, L. Editors, 2011. Lycksalighetens ö. Göteborg, pp. 45-64

Holmes, G. 2007. Protection, Politics and Protest: Understanding Resistance to Conservation. Conservation and Society, 5, (2), pp. 184-201

Honneth, A. 1995. The Struggle for Recognition. The Moral Grammar of Social Conflicts. Polity Press.

Huigen, P., Groote, P., Haartsen, T. 2000. Claiming Rural Identities. Dynamics, Contexts, Policies. Van Gorcum. Netherlands. 
Jacoby, K. 2001. Crimes Against Nature: Squatters, Poachers, Thieves, and the Hidden History of American Conservation. University of California Press.

Jones, D. 1979. The Poacher: A Study in Victorian Crime and Protest. Historical Journal, 22, pp. $825-860$

Krange, O., Skogen, K. 2007. Reflexive tradition: Young working-class hunters between wolves and modernity. Young: Nordic Journal of Youth Research, 15(3): 215-233.

Krange, O., Skogen, K. 2011. When the lads go hunting: The 'hammertown mechanism' and the conflict over wolves in Norway. Ethnography, 12 (4), 466-489.

Kyrkans Tidning 2013. The Church invests in moose hunt

Retrieved at: www.kyrkanstidning.se/inrikes/kyrkan-satsar-pa-algjakt Published 2013-08-30

Liberg, O., Chapron, G.,Wabakken, P., Pedersen, H.C., Thompson, H., Sand, H. 2012. Shoot, shovel and shut up: cryptic poaching slows restoration of a large carnivore in Europe. Proceedings of the Royal Society of Biological Sciences, 279 (1730), pp. 910-915.

Jacobsson, K., Lindblom, J. 2012. Moral Reflexivity and Dramaturgical Action in Social Movement Activism: The Case of the Plowshares and Animal Rights Sweden. Social Movement Studies. Journal of Social, Cultural and Political Protest. 11 (1), pp. 41-60

Linnell, J.D. (2013). From conflict to co-existence: insights from multi-disciplinary research into the relationship between people, large carnivores and institutions. Istituto di Ecologia Applicata. European Commission.

Loehwing, M., Motter, J. 2009. Publics, Counterpublics, and the Promise of Democracy. Philosophy and Rhetoric. 42 (3), pp. 220-241

Lumiaro, R. 1997. Onko sudella olemassaolon mahdollisuutta Suomessa, ihmisten suhtautuminen suteen. Luonto-Liiton julkaisuja 1/1997. 
Manning, R. 1993. Hunters and Poachers: A Social and Cultural History of Unlawful Hunting in England 1485-1640. Oxford University Press.

Mansbridge, J. 1996. Using power/fighting power: The polity. In Benhabib, S. Editor, 1996, Democracy and difference: Contesting the boundaries of the political. Princeton, NJ: Princeton University Press, pp. 46-66

Matti, S., Sandström, A. 2013. The Defining Elements of Advocacy Coalitions: Continuing the Search for Explanations for Coordination and Coalition Structures. Review of Policy Research. 30 (2), pp. 240-257

McCauley, C., Moskalenko, S. 2008. Mechanisms of Political Radicalization: Pathways Toward Terrorism. Terrorism and Political Violence, 20(3), pp. 415-433.

McCauley, C., Moskalenko, S. 2009. Friction: How Radicalisation Happens to Them and Us. Oxford University Press.

McNay, L 2008. The Trouble with Recognition: Subjectivity, Suffering, and Agency. Sociological Theory. 26 (3), pp. 271-296

Meehan, J. 1995. Feminists read Habermas: Gendering the Subject of Discourse. New York: Routledge

Mischi, J. 2008. Les militants ouvriers de la chasse. Éléments sur le rapport des classes populaires au politique. Politix. 83 (3), pp. 133-153

Mischi, J. 2013. Contested rural activities: class, politics, and shooting in the French countryside. Ethnography, 14, pp. 64-84

Moilanen, M. 2014. Varnar för illegal vargjakt. Jaktojägare. Published 2014-03-31 Retrieved at: www.jaktojagare.se/aktuellt/varnar-for-illegal-vargjakt 
Mykrä, S., Pohja-Mykrä, M. 2005. History of Finnish policy concerning the wolf. Management Plan for the Wolf Population in Finland. Ministry of Agriculture and Forestry $11 \mathrm{~b} / 2005$

Muth, R. M., Bowe, J. F. 1998. Illegal harvest of renewable natural resources in North America: Toward a typology of the motivations for poaching. Society and Natural Resources, 11, pp. 9-24.

Nagtzaam, G., Lentini, P. 2008. Vigilantes on the High Seas: The Sea Shepherds and Political Violence. Terrorism and Political Violence, 20, (1), pp. 10-133

Negt, O., Kluge, A. 1972. Public Sphere and Experience: Toward an Analysis of the Bourgeois Public Sphere. Suhrkamp Verlag, Frankfurt

Nilsson Dahlström, Å. 2003. Negotiating Wilderness in a Cultural Landscape: Predators and Saami Reindeer Herding in the Laponian World Heritage Area. Doctoral Dissertation. Department of Cultural Anthropology. Uppsala University.

Nurse, A. 2013. Animal Harm: Perspectives on Why People Harm and Kill Animals. Farnham: Ashgate

Nyrén, U. 2012. Rätt till jakt 1600-1789. Doctoral dissertation. Gothenburg University.

Oinaala, Sampsa. 2012. Suden tappaja. Me susirajan tällä puolella olemme kovin huolissamme petokannoista. Niin on sotkamolainen Kari Tikkunenkin. Helsingin Sanomat. Published: 2012-11-02

Retrieved at: http://www.hs.fi/kuukausiliite/Suden+tappaja/a1305845714484 
Ólafsson, J. 2012. Defiance: A Comment On The Logic Of Protest. TRAMES: A Journal of the Humanities and Social Sciences. 11 (4), pp. 432-442.

Paine, R. 1999. Reindeer theft? Notes on how a culture is put at odds with itself. Acta Borealia: A Nordic Journal of Circumpolar Societies. 16 (1)

Parliament Proposition (2009/1474). Decree on game management delegations. Department of the Environment. Swedish Riksdag.

Passas, N. 1986. Political crime and political offender: Theory and practice. Liverpool Law Review, 8(1), pp. 23-36

Pellikka, J. 2005. Management of wildlife richness in Finnish forests-interplay between game-related actors and actions. Doctoral thesis. Univ of Helsinki.

Peltola, T., Ratamäki, O., Pellikka, J. 2013. Salametsästys ja oikeuttamisen yhteisölliset strategiat. Teoksessa, B. Ismo, B. Jokinen, J. Kotilainen, J. Schuurman, N. Sireni, M. Editors, 2013. Korpisosiologi(aa). University Press of Eastern Finland, Joensuu, pp. 208-223.

Pendleton, M. 1998. Taking the Forest - the shared meaning of tree theft. Society and Natural Resources, 11, pp. 39-50

Persson, M. 2010. Från Torporarkultur till miljardindustri. Högmans. CM-gruppen

Peterson, M. N. 2004. An approach for demonstrating the social legitimacy of hunting. Wildlife Society Bulletin 32(2), pp. 310-321.

Peterson, M., Hansen, H.P., Peterson, M., Peterson, T. 2011. How hunting strengthens social awareness of coupled human-natural systems. Wildlife Biol in Practice; 6 (2), pp. 127-143

Porrovecchio, M. 2007. Lost in the WTO shuffle: publics, counterpublics and the individual. Western Journal of Communication, 71 (3), pp. 235-256 
Pott, M. 2011. Ligné: "Vargkramare liknar nazister" Jaktojägare. Published 2011-11-11

Retrieved at: http://www.jaktojagare.se/ligne-vargkramare-liknar-nazister-1

Pott, M. 2014. Insamling för misstänkta jägare. Jaktojägare. Published 2014-05-02

Retrieved at: http://www.jaktojagare.se/aktuellt/insamling-for-misstankta-jagare

Pyka, M., Nyvqist, A., Monstad, T., Hagstedt, J., Korsell, L. 2007. Illegal jakt på stora rovdjur Konflikt i laglöst land? Brottsförebyggande Rådet. Report 2007:22

Ripatti, J.P. 2013. A sad outcome of an illegal Wolf hunt - there were no winners. Blog at yeswehunt. Published 2013-03-25

Retrieved at: http://yeswehunt.eu/de/main-navigation/blogs/blogs-von-jagern/juha-pekkaripatti/a-sad-outcome-of-an-illegal-wolf-hunt-there-were-no-winners

Rogers, P. 1974. The Waltham Blacks and the Black Act. The Historical Journal, 17 (3), pp. 465-486

Rytterstedt, E. 2013. När stockholmarna åkt hem kan vi släppa lite på reglerna En analys av norrländska jägares kulturella förklaringar till jaktbrott. Bachelor thesis. Department of Sociology. Lund University.

Sandström, C., Pellika, J., Ratamäki, O. 2009. Management of Large Carnivores in Fennoscandia: New Patterns of Regional Participation. Human Dimensions of Wildlife 14(1), pp. 37-50

Scheff, T. Retziner, S. 1991. Emotions and Violence: Shame and Rage in Destructive Conflicts. American Journal of Sociology. 98 (3), pp. 664-666 
Schmid, A. 2013. Radicalisation, De-Radicalisation and Counter-Radicalisation: A Conceptual Discussion and Literature Review. The Hague, International Centre for CounterTerrorism, March; Research Paper, pp. 1-91

Scott, J.C. 1985. Weapons of the Weak: Everyday Forms of Peasant Resistance. Yale University Press

Sjölander-Lindqvist, A. 2008. Local Identity, Science and Politics Indivisible: The Swedish Wolf Controversy Deconstructed. Journal of Environmental Policy and Planning; 10 (1), pp. 71-94.

Sjölander-Lindqvist, A. 2009. Social-Natural Landscape Reorganized: Swedish Forest-edge Farmers and Wolf Recovery. Journal of Conservation and Society; 7 (2), pp. 130-140.

Sjölander-Lindqvist, A., Karlsson, M., Cinque, S. 2010. Att jaga varg: En studie av 2010 års licensjakt i Sverige. Report for Center for Public Sector Research. Gothenberg University

Sjölander-Lindqvist, A. 2011. Predators in 'Agri-environmental' Sweden: Rural Heritage and Resistance Against Wolf Propagation. In Gökçekus, H. Türker, U. Lamoreaux, J.W. Editors, 2011. Survival and Sustainability: Environmental concerns in the 21st Century, pp. 15-27

Skogen, K., Mauz, I. and Krange, O. 2008. Cry Wolf! Narratives of wolf recovery in France and Norway. Rural Sociology 73(1), pp. 105-133.

Squires, C, R. 2002. Rethinking the Black Public Sphere: An Alternative Vocabulary for Multiple Public Spheres. Communication Theory, 12 (4), pp. 446-468

Swan, J. 1995. In Defense of Hunting. Harper Collins Publishers, New York

Sziarto, K.M., Leitner, H. 2010. Immigrants riding for justice: space-time and emotions in the construction of a counter-public. Political Geography, 29, pp. 381-391 
Taylor, C. (1994). Multiculturalism and "The Politics of Recognition". Princeton University Press. ISBN: 9780691037790

Thompson, E. P. 1975. Whigs and hunters: The origin of the Black Act. London: Breviary Stuff Publications

Tillhagen, C. H. 1987. Allmogejakt i Sverige. LTs förlag. Stockholm

von Essen, E., Hansen, H.P., Nordström Källström, H., Peterson, M. N., Peterson, T.R. 2014.

Deconstructing the Poaching Phenomenon: A Review of Typologies for Understanding Illegal Hunting. British Journal of Criminology. 54 (4), pp. 632-651

Warner, M. 2005. Publics and Counterpublics. Zone Books.

Wimmer, J. 2005. Counter-Public Spheres and Revival of the European Public Sphere. Javnost - The Public. 12 (2), pp. 93-110

Woods, M. 2003. Deconstructing Rural Protest - The Emergence of a New Social Movement, Rural Studies, 3, pp. 309-25.

Woods, M. 2005. Defining the rural. In: Woods, M. Rural Geography, 2005. London: Sage, Chapter 1: 3-16

Zimmermann. B., Wabakken. P., Dötterer, M. 2001. Human-carnivore interactions in Norway: How does the re-appearance of large carnivores affect people's attitudes and levels of fear? Snow Landscape Research, 76, pp. 137-153 